\title{
EDUCATION IN TIMES OF COVID-19: CHALLENGES AND OPPORTUNITIES
}

\author{
ALBERT MIYER SUAREZ ${ }^{1}$, ROSSY VILLAMARÍN PEREZ ${ }^{2}$ \& SIR-ALEXCI SUAREZ ${ }^{3}$ \\ ${ }^{I}$ Engineering Faculty. University of Pamplona, Colombia \\ ${ }^{3}$ Engineering Faculty, University Francisco of Paula Santander Ocaña, Colombia
}

\begin{abstract}
Education has been interrupted for a whole generation and the fact is that COVID-19 put the whole world in check, generating a crisis without antecedents in all sectors, where one of the areas most affected was education, being forced to respond urgently to the crisis, making the massive closure of academia institutions in order to avoid and mitigate the impact of the pandemic.

KEYWORDS: COVID-19, Online Teaching, Educational Reform
\end{abstract}

Received: Nov 05, 2020; Accepted: Nov 25, 2020; Published: Dec 04, 2020; Paper Id.: IJMPERDDEC20206

\section{INTRODUCTION}

At the educational level, countries worldwide have adopted extreme measures in the face of the COVID-19 crisis (Leguizamon, 2020; Saavedra-Camacho and Iglesias-Osores, 2020), one of them is related to the suspension of faceto-face classes in all levels because the traditional classroom is a source of potential contagion, generating three main fields of action: 1) Distance learning, through the use of a variety of formats and platforms (with or without the use of technology); 2) Support and mobility of staff and educational communities, 3) Attention to health and comprehensive well-being of students.

For this reason, the representative of the World Health Organization (WHO) Mike Ryan, emphasized that the return to class must be gradual, orderly and staggered, since "the return to school in contexts of intense transmission (of the virus) in the community it is very difficult. Even in places with few cases, caution is required" (EFE, 2020). While UNICEF (2020) shows the return to school and what the situation is like in several countries in the pandemic.

Since President Ivan Duque ordered the closure of educational institutions in Colombia on March 19, 2020 (ELTIEMPO, 2020), there has been a crisis motivated by COVID-19, without the relevant authorities having enough time in order to establish guidelines or develop a minimum contingency plan and where administrators, teachers and students face the crisis and learning cannot be stopped or postponed, which generates a titanic and joint effort in the application of different plans contingency and strategies (virtual, pedagogical workshops, guides, among others) working against the clock in just a few weeks, taking into account the context and location of educational venues, where one of the most used is virtuality. All these implications must be reviewed in order to carry out contingency plans in a timely manner (Almeida-Espinosa and Sarmiento-Ardila, 2020).

According to Gagné (1987) "Learning consists of a change in the human disposition or capacity, with a character of relative permanence and that is not simply attributable to the development process" (Page 43).

It is possible that one of the last activities that will be allowed again in the country is the return of students to 
classrooms, without a vaccine for COVID-19. For this reason, for a long time we will have millions of people facing a new way of teaching and learning. Where the majority are students in a period of compulsory schooling, teachers few experts in the management of virtual media and on the other hand teachers of the old school who refuse to leave their comfort zone using traditional methods and is to change the way of teach classes, fight against the problems of students without Internet access, students who do not have computers, achieve the attention of both children and young people, fight with upset parents and how to effectively monitor their teaching and learning process; highlighted the lack of preparation and organization of many teachers and institutions, even with virtual platforms.

The purpose of this research is to visualize the consequences that the measures have on educational communities in the short and medium term, describing and analyzing the factors that intervene in the different educational context of the country caused by COVID-19.

\section{ADAPT COMPULSORY TEACHING TO AN ONLINE SYSTEM}

According to the author Fidias Arias (2012) defines: descriptive research consists of the characterization of an event, phenomenon, individual or group, in order to establish its structure or behavior. The results of this type of research are located at an intermediate level in terms of the depth of knowledge is concerned (page 24). Covid-19 came to change the educational scenario. There is uncertainty, desolation and frustration in the atmosphere, but also a heroic and daily effort. By teachers, students and administrators. Demonstrating with actions his vocation and sacrifice. Pushing ourselves to the fullest not to allow this virus to paralyze us as a society, to coexist creatively and to learn to live optimistically in this crisis that is being experienced worldwide. In Colombia, implementing an online education model overnight, motivated by a pandemic, is a great opportunity to get closer to our students, adapting the Methodology. That within Pedagogy, it establishes appropriate procedures, techniques, activities, exercises and everything that allows the exchange of knowledge between the teacher and the student, in each area. On the other hand, the sector and the context of the students (rural, urban) must be taken into account.

According to Dane (2020) in the technical informative bulletin presented on June 4, 2020, the students enrolled in $2019,7,654,108$ (76.3\%) were attended in educational centers located in urban areas and 2,382,332 (23, 7\%) in educational centers in rural areas (Figure 1).
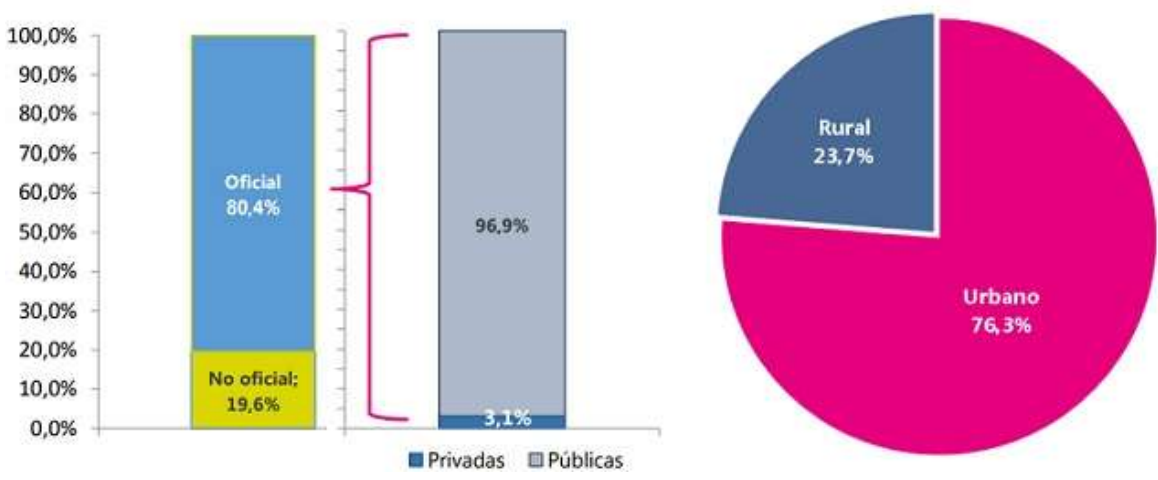

Figure 1: March 2020 Percentage distributor of students enrolled by sector and area - Total 2019 (DANE, 2020).

Where the largest number of students enrolled was in elementary school with $42.2 \%$ of the total enrollment, followed by secondary school with $34.4 \%$, distributed in 47,951 schools, where the largest number of schools focus their services on the elementary school level where $73.0 \%$ are part of campuses located in rural areas and $27.0 \%$ in urban areas (Figure 2). 


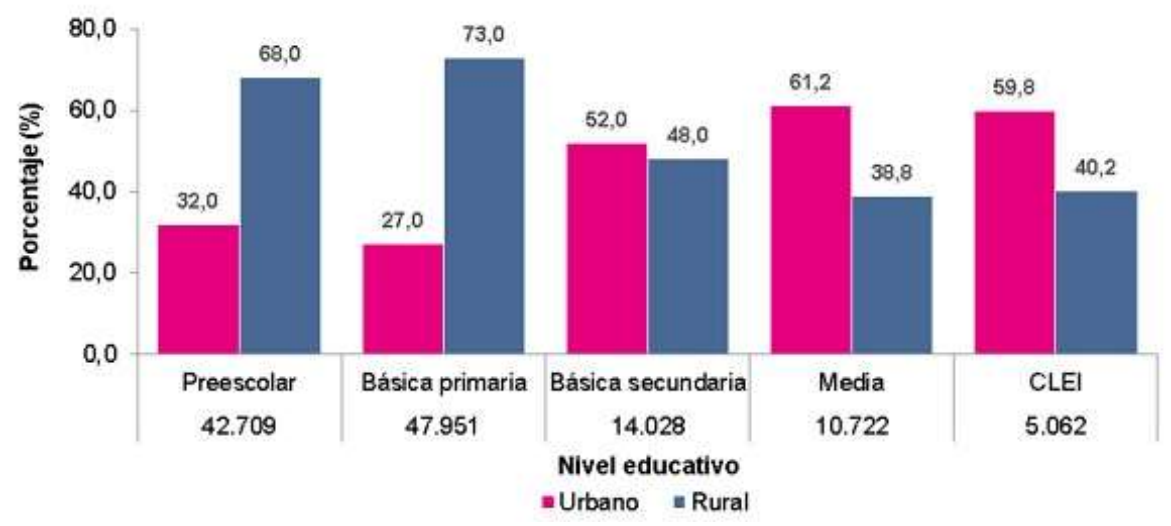

Figure 2: Number of campuses and percentage distribution, by educational level and area - National total 2019

(DANE, 2020)

Of these locations, 93.2\% have electricity, and only $11.2 \%$ have local air network (LAN) service. Of the remaining headquarters of the unofficial sector; $98.2 \%$ had public electricity service, and the lowest percentage was for radio service $39.5 \%$ (Figure 3).

\begin{tabular}{lcccr}
\hline \multirow{2}{*}{ Bienes y servicios TIC } & \multicolumn{3}{c}{ Sector } & \multicolumn{2}{c}{ Zona } \\
\cline { 2 - 6 } & \multicolumn{1}{c}{ Oficial } & No Oficial & Urbano & Rural \\
\hline Electricidad & 93,2 & 98,2 & 97,9 & 92,1 \\
Televisión & 36,0 & 78,5 & 67,3 & 31,7 \\
Línea Telefónica & 14,6 & 89,9 & 73,4 & 5,2 \\
Radio & 12,1 & 39,5 & 28,6 & 11,3 \\
LAN & 11,2 & 57,1 & 45,5 & 6,3 \\
Internet & 33,9 & 97,1 & 91,9 & \\
Bienes TIC & 89,3 & 94,6 & 95,9 & 21,3 \\
\hline
\end{tabular}

Figure 3: Percentage participation of educational centers according to ICT goods and services by sector and area Total 2019 (DANE, 2020)

In relation to the numbers and statistics registered in DANE, it is shown that there is a high rate of educational centers and students in both the rural and urban sectors that do not have the access or the means to acquire the technological devices necessary to access a school, Virtual platform where the most affected students are those from the rural sector.

Motivated by this, teachers in the rural sector face a greater problem since face-to-face classes were suspended, as they cannot use platforms such as Zoom, Meet, Jeans, Moodle and Blackboard, among others, or the different social networks to interact with students and parents, a totally different context from teachers in the urban sector, since $90 \%$ of students have the necessary means to enter online classes. But without any prior training they started classes far from the classroom, but in a more impersonal way.

Around this, the Economic Commission for Latin America and the Caribbean (ECLAC, 2020) "has stated that, even before facing the pandemic, the social situation in the region was deteriorating, due to the increase in poverty and poverty rates. Extreme, the persistence of inequalities and growing social discontent. In this context, the crisis will have important negative effects on the different social sectors, including particularly health and education, as well as on employment and the evolution of poverty". For its part, UNESCO (2013) has identified large gaps in educational results, which are related to an unequal distribution of teachers, in general, and of the best-qualified teachers, in particular, to the detriment of countries 
and regions with less income and rural areas,

Our country does not escape this reality, where $327,698(72.2 \%)$ teachers who provide their services in educational centers in urban areas and 126,170 (27.8\%) teachers in rural areas (Figure 4).

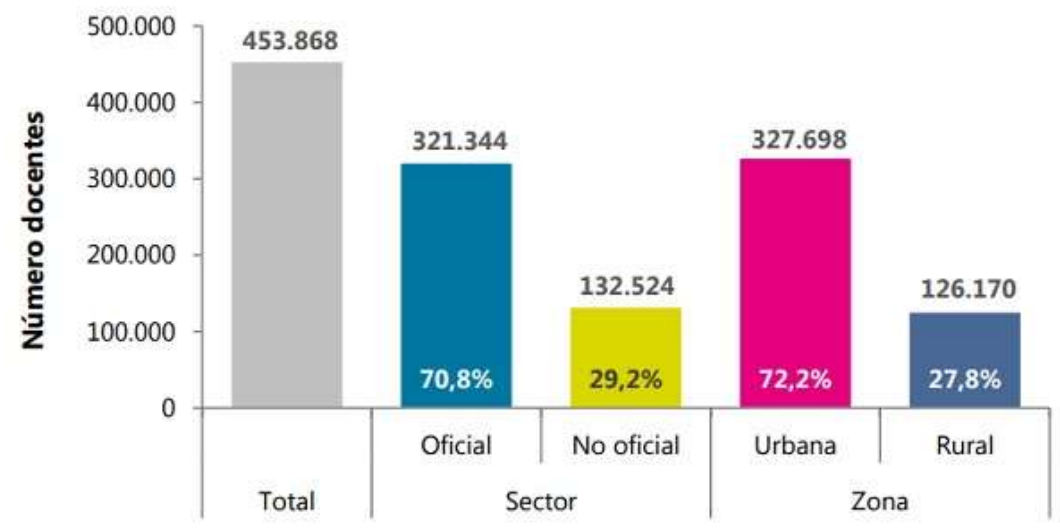

Figure 4: Number and percentage distribution of teachers with academic assignment by sector and area - National total 2019 Source: (DANE, 2020)

Teachers in the rural sector make a joint effort to reach their students with school activities (guides, workshops, pedagogical material, among others), walking long distances, often crossing bridle paths or using horses, mules, motorcycles or jeeps to be able to reach your destination, in sectors where technology does not exist.

However, we must take advantage of a very important factor in this era and that is that our students have changed their way of learning and that is that they are digital natives, technology is part of their life, from the first moment they come into the world. Their minds do not envision a non-technological world.

The objective is not to change the paradigm of the educational system, but to continue, maintaining work guidelines, the face-to-face classes interrupted by a distressing health emergency. Changing the rules of the game of the academic year with concerns such as: what can be done to adapt compulsory classroom teaching to an online system?

Although the easiest thing would have been to put homework, assignments and let the parents and each student take charge of their training for a while, to continue alone, each with their texts and at home. Many teachers planned it this way in the first weeks of confinement. But as the period of confinement was extended, the need to change methodological strategies was seen.

Virtuality consists of a mediated model, that is, it uses the computer or other information exchange devices between people (students and teachers). Success depends on both being involved and committed, also on didactic materials, based on the principles of active, collaborative, autonomous, interactive, comprehensive learning, with relevant and creative activities or tasks.

According to ANUIES (ANUEIS, 1999), online teaching, has a multiplying and enriching effect of face-to-face education, since it favors and strengthens teamwork, learning based on problem solving, communication skills, creativity and capacity to innovate. On the other hand, the United States Congress in 1992, to differentiate Distance Education from other forms of learning, defined it as "the transmission of education or instructional programming to geographically dispersed individuals or groups" (Alvarez Gómez, 2005). 
Deliberately done online education is not as simple as sending packages home or telling students which YouTube videos to watch and when done correctly it is just as rewarding as teaching in person.

\section{Rethinking and Relearning Pedagogy}

Before the crisis caused by COVID-19, very few teachers received any kind of training on how to teach an online class, and the more traditional a teacher taught, the better their comfort zone, they did not consider taking an online class, let alone experienced a virtual class themselves.

However, students have evolved in their technological mastery and the responsibility of keeping students motivated is different over the internet, so teachers wonder about: What have I done during the school year? What excited them and how can I use the same strategies and skills? Do I need to have power over my students or empower them to think for themselves?

\section{Family Involvement}

COVID-19, in addition to causing an unprecedented crisis and without writing the script in the best Hollywood style, achieved a new level of family participation, this is not easy and more when most of the parents are working and even If they are not, they may not act as learning advisors, however the pandemic has even managed to make parents a link between the teacher and the students, becoming the personal teachers of their children.

Where in most cases teachers must explain the issues to parents so that they in turn explain them in the best way to their children. Most parents are not prepared to be teachers themselves, they may have knowledge and know what is the learning style that their child has, how long he can concentrate or what stimulates him, but not how to explain school activities.

\section{Success in this new educational era}

The pandemic placed virtual education on the table as an opportunity for the education sector to continue operating and the learning of thousands of children and adolescents does not stop. But to get ahead in this situation we must take into account several factors:

\section{Connectivity}

Internet access is one of the first factors that must be taken into account to implement an online model. However, the situation in our country is quite worrying, when reviewing the statistics offered by the National Administrative Department of Statistics (DANE) indicating that only around $26 \%$ of students in rural areas have connectivity compared to $89 \%$ in urban areas . Resulting a challenge of a financial and educational nature to generate educational communities around the appropriation of technology as a mediation of teaching.

\section{Feedback: (student, teacher and parent)}

ICTs in education allow immediate personalized feedback and corrections. But at the same time it presents great risks such as: dispersion, the feeling of loneliness, the frustration of not having technological knowledge and the fact that a greater effort must be made than usual. Where teachers must ensure that these risks are minimized

As with traditional methodologies, where the classroom favors the theoretical and visual, this traditional technique has a negative influence when addressing online teaching. Without leaving aside the most important thing: in the online mode, one of those involved in the process, the student, has to be freely and spontaneously involved in their learning, which 
is opposed to the traditional model, based on authority and the obligation. Which will allow the student to control their own pace and schedule. At the same time, the student can develop various skills through a wide variety of activities; allowing repetition according to the student's needs without pressure, thereby reducing inhibition, reducing the fear of intervening and the anxiety produced by the fear of making mistakes.

\section{The context (student)}

One of the main factors for the success of this new modality is the context that surrounds the student, from their economic situation, to the educational level of the people around them, the most affected by this situation are students from the rural sector, where $99 \%$ of them do not have internet access, little telephone signal and where $50 \%$ of the parents do not have a high academic degree, another $30 \%$ of the population cannot read or write, in addition to considering the great distances that exist between the houses or farms that are part of the village where they live, which prevents collaborative and cooperative work among students. Placing in check the teachers who must invent great methodological strategies to bring knowledge to their students without them falling behind or deserting the education sector.

\section{Evaluation}

It is also important to refer to the evaluation system and it is that educational institution had to make adjustments based on the COVID-19 pandemic to their Institutional Student Evaluation System (SIEE), where the traditional evaluation was implemented, where to a large extent Part consists of rigorous evaluation through various assessment techniques, sometimes isolating students from any source of information during the assessment. This is impossible in the online methodology.

In virtual education, the evaluation is constant and with a high degree of flexibility, the teacher must apply different types of evaluative strategies that allow him to verify the student's performance, in virtuality the student can take the exam accompanied by all the material he wishes and even, contrast their answers with a group of colleagues in real time. For this reason, it is important to design evaluations that constantly assess the development of competencies.

\section{CONCLUSIONS}

COVID-19 brought great changes in our daily lives and the situation presented by the pandemic does not give options, today education abruptly goes from the face-to-face to the virtual environment, challenging teachers, students and administrators of all educational levels to evolve whether or not they want to leave their comfort zone.

Education must evolve along with the available technology and forces us to think about the methods and strategies that we use as teachers to acquire, transmit and build knowledge, always thinking about the context and the best for the student, where many of the methods Used in person, they do not work in virtuality, which has its own characteristics in terms of spaces, times, resources, communication and interaction, therefore, it requires differentiated teaching strategies.

It is time for change, but we are really trained to face it. Going to the main thing, in any of its circumstances the teaching-learning process consists of an exchange of knowledge and skills between people (taking into account in the online mode, the digital divide that still exists in a large percentage of the teaching population and the student body).

The return to classes should be done gradually, locating disinfection points in schools so that the educational community can wash their hands frequently and taking into account all the required biosecurity measures, in addition to monitoring any possible case of contagion. 


\section{REFERENCES}

1. Almeida-Espinosa, A., y Sarmiento-Ardila, J. (2020). COVID-19: Implicaciones en Colombia. Gaceta medica de Mexico, 156. https://doi.org/10.24875/GMM.20000289

2. Alvarez Gómez, M. (2005). Aprendizaje en línea. Guadalajara, Jal.: Universidad de Guadalajara, Centro Universitario de la Costa.

3. ANUEIS. (1999). Cooperación, movilidad estudiantil e intercambio académico. Líneas estratégicas para su desarrollo. Colima. ANUIES

4. Arias, F. G. (2012). El Proyecto de Investigación. Introducción a la Metodología Científica. 5ta. Edición (6a. ed.). Fidias G. Arias Odón.

5. CEPAL. (2020). La educación en tiempos de la pandemia de COVID-19. CEPAL. Recuperado de https://www.cepal.org/es/publicaciones/45904-la-educacion-tiempos-la-pandemia-covid-19

6. DANE. (2020). Boletín técnico Educación formal (EDUC) 2019. Recuperado de https://www.dane.gov.co/files/investigaciones/boletines/educacion/bol_EDUC_19.pdf

7. EFE. (2020). OMS: Vuelta al colegio será segura si la transmisión local del virus es baja. Recuperado 15 de octubre de 2020 , de Www.vanguardia.com website: https://www.vanguardia.com/mundo/oms-vuelta-al-colegio-sera-segura-si-la-transmisionlocal-del-virus-es-baja-FY2771878

8. ELTIEMPO. (2020). Se suspenden clases presenciales en todos los colegios del país. Recuperado 15 de octubre de 2020 , de El Tiempo website: https://www.eltiempo.com/politica/coronavirus-en-colombia-se-suspenden-clases-presenciales-en-colegiospublicos-y-privados- 473100

9. Gagne, R. M. (1987). Las condiciones del aprendizaje (p 43). México, D.F.: Interamericana.

10. Leguizamon, J. (2020). La educación superior pública en Colombia ante el Covid-19. CAMINHOS DA EDUCAÇÃO: diálogos, culturas e diversidades, 2, 85-102. https://doi.org/10.26694/caedu.v2i2.11239

11. Saavedra-Camacho, J., y Iglesias-Osores, S. (2020). Medidas gubernamentales de contención COVID-19. https://doi.org/10.5281/zenodo.3842101

12. UNESCO. (2013). Situación Educativa de América Latina y el Caribe: Hacia la educación de calidad para todos al 2015. Recuperado de http://www.unesco.org/new/fileadmin/MULTIMEDIA/FIELD/Santiago/images/SITIED-espanol.pdf

13. UNICEF. (2020). Regresar a la escuela en época de pandemia. Recuperado 15 de octubre de 2020, de https://www.unicef.org/es/coronavirus/regreso-escuela-pandemia 

